\begin{tabular}{ll}
\hline 原 & 著 \\
\hline
\end{tabular}

\title{
1973年岐阜県で流行した Hand, Foot and Mouth Disease におけるウイルス学的研究
}

\author{
三輪 智 恵子* 山田不二 造* \\ 松 浦 章 雄** 吉 沢 邦 重*** \\ * 岐阜県衛生研究所 \\ ** 高山赤十字病院小児科 \\ *** 多治見病院小児科
}

〔受付：3 月15日，1978年〕

1973年，岐阜県で Hand，Foot and Mouth Disease（HFMD）が流行した. 42名の患 者につきウイルス学的血清学的に検索した.

患者の年齢は 0 歳から 23 歳に及んでいたが， 4 歳以下の小児が $71.4 \%$ 占めた． 42 症例 中，中枢神経症状を合併した症例が 20 症例あった.

ウイルスは38例中22例 $(57.9 \%$ ) より分離された. Enterovirus 71 (EV-71) が16症例 (42.1\%), Coxsackievirus (Cox.) B-5 が 8 症例 (21.1\%), Cox. A-9 が 2 症例 (5.2\%), 同定不能ウイルスが 1 症例 (2.6\%) より分離された. EV-71はVero 細胞で18株，乳のみ マウスで 1 株分離された。 中枢神経症状を合併した症例より分離されたウイルスは EV-71 と Cox. B-5であった.

分離された EV-71は交差中和試験で，Cox. A-16とは交差がなく，EV-71標準株とは交 差が認められたが，標準株より抗原的に broad であった。

ペア血清24例中，EV-71が $25 \% ，$ Cox. A-16が $4 \% ％$ 23例中 Cox. B-5 が $13 \% ， 6$ 例中 Cox. A-9 が17\%，それぞれ中和抗体の有意上昇が認められた.

1973年岐阜県で流行した HFMD の主病原ウイルスは EV-71であると推定される. しか し，ほかの分離ウイルスも病因的役割を否定できない．

外国では, HFMD について1957年の流行を Robinson

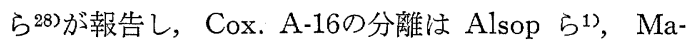
goffin ら ${ }^{16)}$ によってなされた. 日本では, 中村ら22)がこ の疾患について1963年の散発例について報告し，1967年

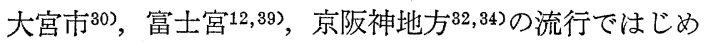
て Cox. A-16が分離されている. 1970年にわが国で流 行した HFMD の病原ウイルスは Cox. A-16である. その臨床像は皮膚粘膜症状が主であったが36)，1973年岐 阜県で流行した HFMD は髄膜炎・脳炎が合併症として 認められた．1973年の HFMD の流行については，他県 でも髄膜炎の合併が多く報告されている $9,13,23,27,37)$.
著者らは, HFMD 患者材料よりウイルス分離を試み, 血清学的にも検討した結果, 1973年の HFMD の流行は, Cox. A-16とは異なった新しい型の Enterovirus $71^{18}$ )が 病原ウイルスであることを確認したのでここに報告す る.

\section{材料と方法}

1. 被検材料：多治見病院小児科および高山赤十字 病院小児科に来院した HFMD 患者それぞれ16名と26名 計 42 名につき，咽頭ぬぐ、液36件，䯣液 8 件，ふ儿便 30 件である，患者血清はペア血清 24 件，単独血清15件であ 
表 1 Viruses used in neutralization test

\begin{tabular}{cccl}
\hline Virus type & Virus code & Passage history & History \\
\hline $\begin{array}{c}\text { Coxsackievirus } \\
\text { A-16 }\end{array}$ & Cox. A-16(G-10) & SM-2, MK-1, Vero-2 & from Dr. Komatsu in NIH \\
$\begin{array}{c}\text { Coxsackievirus } \\
\text { A-9 }\end{array}$ & T-73-9-F & MK-2 & $\begin{array}{l}\text { Isolate from faeces of HFMD patient } \\
\text { in Gifu in 1973 }\end{array}$ \\
$\begin{array}{c}\text { Coxsackievirus } \\
\text { B-5 }\end{array}$ & Ty-12-F & HeLa-2 & $\begin{array}{l}\text { Isolate from faeces of HFMD patients } \\
\text { in Gifu in 1973 }\end{array}$ \\
Ty-3-F & T-73-6-F & MK-2, HeLa-1 & HeLa-3 \\
Enterovirus-71 & Ozawa & Vero-4 & $\begin{array}{l}\text { Isolate from vesicle fluid of HFMD } \\
\text { patient in Nagoya in 1973 (from Dr. } \\
\text { Nakamura) }\end{array}$
\end{tabular}

る.

2. ウイルス分離に使用した細胞および動物： カニ クイザル初代腎細胞(MK), HeLa 細胞(野生株), Vero 細胞 (名古屋市衛研より分与)，乳のみマウスを使用し た.すべての検査材料は $\mathrm{MK}$ と $\mathrm{HeLa}$ で試みたが, Vero 細胞は一部材料に限って試みた。乳のみマウスは 主としてふん便材料に試みられた。詳細は既報 ${ }^{20,21)}$ と同 じである.

3. ウイルス分離方法および分離ウイルスの定量 : 既報 ${ }^{20,21)}$ とほとんど同じ方法を用いた. HeLa 細胞で Cox. B-5 が分離された材料は，Cox. B-5 標準株家兔免 疫血清の 1,000 単位を材料に等量に加え, $37^{\circ} \mathrm{C} 60$ 分中和 後, Vero 細胞に接種し, 再分離を試みた.

4. 分離ウイルスの同定：同定に用いた抗血清は国 立予防衛生研究所腸内ウイルス部より分与を受けたエン テロウイルス同定用血清のほかに, Cox. A-16標準株家 鬼免疫血清, 1973年 HFMD 患者より 分離した T-7323-Th 株で免疫した家鬼血清， EV-71標準株 (BrCr) で 先疫した家鬼血清を用いた. 詳細注既報20)と同じである.

5. 患者血清の中和抗体価の測定：用いたウイルス は表 1 に示した. ウイルスは $100 \mathrm{TCID}_{50} / 0.1 \mathrm{ml}$ と 4 倍 段階希釈した患者血清の $0.3 \mathrm{ml}$ を等量混合し， $37^{\circ} \mathrm{C} 2$ 時閒 water bath で反応後, 維持液に代えた細胞のチュ ーブ 2 本に0.2ml ずつ接種し， 7 日間 $\mathrm{CPE}$ を観察し， 中和抗体価を Reed-Muench の方法で計算した.

6. 抗血清の作製 : Cox. A-16標準株 (G-10), 1973 年分離代表株 (T-73-23-Th, Ty-22-F)，EV-71 (BrCr) などはVero 細胞に 継代後 $3,000 \mathrm{rpm}, 20$ 分遠心上清を Polyethylen Glycol 6,000 (和光) で約 1/10 に濃縮し, Phosphate buffer saline (PBS $(+))$ خ゙ 1 晚透析した virus 液を免疫抗原とした. 約 $2.5 \mathrm{~kg}$ の家鬼に $2 \sim 3$ 日 間隔で $5 \mathrm{ml}$ ず 5 回静注後, $4 \sim 5$ 週間後に $10 \mathrm{ml}$ のウ イルス抗原を追加免疫として静注し， 1 週間後に全採血 した.

7. 交差中和試験 : Cox. A-16 (G-10), EV-71 (Br-

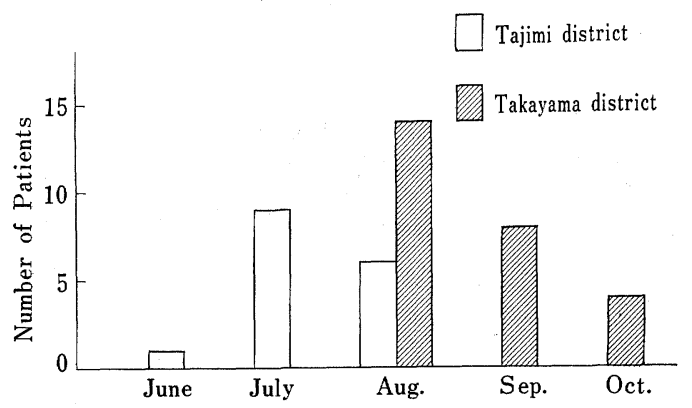

図 1 Number of patients with HFMD

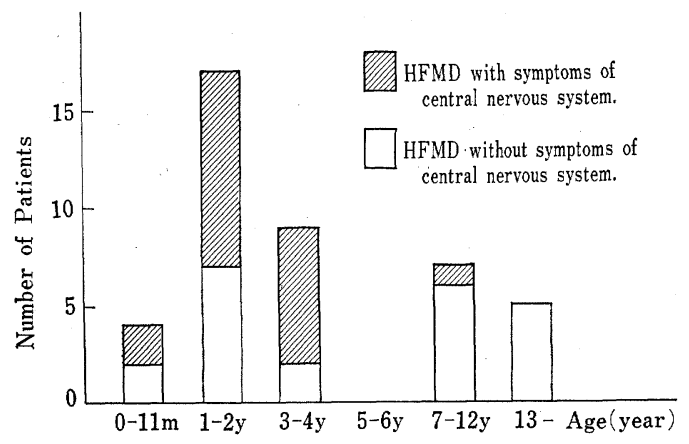

図 2 Age distribution of patients with HFMD Cr)，T-73-23-Th. Ty-22-F に対する家兔质血清を 4 倍段階希釈し， $100 \mathrm{TCID} 50 / 0.1 \mathrm{ml}$ のウイルスの等量を 加え, $37^{\circ} \mathrm{C} 2$ 時間中和後, 維持液に代えた Vero 細胞 に0.2ml ずっ 4 本の試験管に接種し， 7 日間静置培垗し た. CPE の出現率によって血清の中和抗体価を ReedMuench 法で計算した.

\section{成 績}

1. HFMD の流行：検查した患者の月別発生状況 は，図1に示されるようであった，多治見地方では 6 8月に流行し, 高山地方では $8 \sim 10$ 月に流行が認められ た. 患者の年齢分布は $0 \sim 23$ 歳に及んでいるが， 4 歳以 下の小児が全体の $71.4 \%$ 占めていた. 図 2 に示される 
三輪・山田・松浦・吉沢

表 2 Virus types isolated from HFMD patients

\begin{tabular}{|c|c|c|c|c|c|c|c|}
\hline $\begin{array}{l}\text { Case } \\
\text { (No.) }\end{array}$ & $\begin{array}{c}\text { Virus } \\
\text { isolation } \\
(\%)\end{array}$ & $\mathrm{EV}-71$ & $\begin{array}{c}\mathrm{EV}-71 \\
+ \\
\text { Cox. B-5 }\end{array}$ & $\begin{array}{c}\text { EV-71 } \\
+ \\
\text { Cox.A-9 }\end{array}$ & Cox. B-5 & Cox.A-9 & $\begin{array}{l}\text { unidenti- } \\
\text { fied }\end{array}$ \\
\hline $\begin{array}{c}\text { HFMD }+ \text { Encephalitis } \\
(2)\end{array}$ & $\begin{array}{c}1 \\
(50.0)\end{array}$ & 0 & $\begin{array}{c}1 \\
(50.0)\end{array}$ & 0 & 0 & 0 & 0 \\
\hline $\begin{array}{c}\mathrm{HFMD}+\text { Aseptic meningitis } \\
(18)\end{array}$ & $\begin{array}{l}11 \\
(61.1)\end{array}$ & $\begin{array}{c}7 \\
(38.9)\end{array}$ & $\begin{array}{c}3 \\
(16.7)\end{array}$ & 0 & 0 & 0 & $\begin{array}{l}1 \\
(5.6)\end{array}$ \\
\hline $\begin{array}{l}\text { HFMD only } \\
\qquad(18)\end{array}$ & $\begin{array}{l}10 \\
(55.6)\end{array}$ & $\begin{array}{c}4 \\
(22.2)\end{array}$ & 0 & $\begin{array}{l}1 \\
(5.6)\end{array}$ & $\begin{array}{c}4 \\
(22.2)\end{array}$ & $\begin{array}{c}1 \\
(5.6)\end{array}$ & 0 \\
\hline$(38)$ & $\begin{array}{l}22 \\
(57.9)\end{array}$ & $\begin{array}{l}11 \\
(28.9)\end{array}$ & $\begin{array}{c}4 \\
(10.5)\end{array}$ & $\begin{array}{l}1 \\
(2.6)\end{array}$ & $\begin{array}{c}4 \\
(10.5)\end{array}$ & $\begin{array}{l}1 \\
(2.6)\end{array}$ & $\begin{array}{l}1 \\
(2.6)\end{array}$ \\
\hline
\end{tabular}

EV-71: Enterovirus $71 \quad$ Cox. B-5: Coxsackievirus B 5 Cox. A-9: Coxsackievirus A 9

表 3 Virus isolation rate and virus types isolated by various methods

\begin{tabular}{|c|c|c|c|c|c|c|c|}
\hline \multirow{2}{*}{ Method } & \multirow{2}{*}{ Specimen } & \multirow{2}{*}{ (No.) } & \multirow{2}{*}{$\begin{array}{c}\text { Virus isolation } \\
(\%)\end{array}$} & \multicolumn{4}{|c|}{ Virus types isolated } \\
\hline & & & & EV-71 & Cox. B-5 & Cox. A-9 & unidentified \\
\hline \multirow{3}{*}{ MK } & \multirow{3}{*}{$\begin{array}{l}\text { Th. Sw. } \\
\text { C.S.F. } \\
\text { Faeces }\end{array}$} & $(36)$ & $2(5.5)$ & 0 & 0 & 2 & 0 \\
\hline & & $(8)$ & $0(0.0)$ & 0 & 0 & 0 & 0 \\
\hline & & $(30)$ & $4(13.3)$ & 0 & 1 & 2 & 1 \\
\hline \multirow{3}{*}{$\mathrm{HeLa}$} & \multirow{3}{*}{$\begin{array}{l}\text { Th. Sw. } \\
\text { C.S.F. } \\
\text { Faeces }\end{array}$} & $(34)$ & $4(11.8)$ & 0 & 4 & 0 & 0 \\
\hline & & $(6)$ & $1(16.7)$ & 0 & 1 & 0 & 0 \\
\hline & & $(30)$ & $4(13.3)$ & 0 & 4 & 0 & 0 \\
\hline \multirow{3}{*}{ Vero } & \multirow{3}{*}{$\begin{array}{l}\text { Th. Sw. } \\
\text { C.S.F. } \\
\text { Faeces }\end{array}$} & $(15)$ & $4(26.7)$ & 4 & 0 & 0 & 0 \\
\hline & & $(5)$ & $0(0.0)$ & 0 & 0 & 0 & 0 \\
\hline & & $(24)$ & $16(66.7)$ & 14 & 1 & 1 & 0 \\
\hline \multirow{3}{*}{ S.M. } & \multirow{3}{*}{$\begin{array}{l}\text { Th. Sw. } \\
\text { C.S.F. } \\
\text { Faeces }\end{array}$} & (4) & $0(0.0)$ & 0 & 0 & 0 & 0 \\
\hline & & $(1)$ & $0(0.0)$ & 0 & 0 & 0 & 0 \\
\hline & & ( 21$)$ & $1(4.8)$ & 1 & 0 & 0 & 0 \\
\hline
\end{tabular}

S.M. : Suckling mice

Cox. B-5: Coxsackievirus B 5
EV-71: Enterovirus 71

C.S.F. : Cerebrospinal fluid
Th.Sw. : Throat swabs

Cox. A-9: Coxsackievirus A 9
ように，42名の HFMD 患者中20名に中枢神経症状の合 併が認められた。

2. ウイルス分離：表 2 に示すよらに,脳炎を合併し た症例の 1 名からはウイルスは分離されなかった：ほか の1名の髄液から Cox. B-5 が分離され，ふん便からは EV-71 C Cox. B-5 が分離された。 無菌性髄膜炎が合併 した症例では，7症例より EV-71が単独分離され， 3 症例より EV-71とCox. B-5 が重複分離された. 1 症例 より Schmidt pool 血清で同定不能のウイルスが分離 された.このウイルスは乳のみマウスに感染力が認めら れた. 皮膚症状のみの患者からは，4症例より EV-71が 単独分離され，1症例より EV-71とCox. A-9 が重複 分離され，4症例より Cox. B-5 が単独分離され， 1 症
例より Cox. A-9 が単独分離された.

組織培養細胞でのウイルス分離 : MK 細胞では Cox.A-9 4 株と Cox. B-5 1 株が分離された. HeLa 細胞 では Cox. B-5 9 株が分離された. 通常 Enterovirus の分離は MK 細胞が優れているとされていたので, MK 細胞と HeLa 細胞及び乳のみマウスで分離が終わった検 体については材料を一部廃棄した。 しかし，検体採取よ り約 1 年 3 か月後に保存していた検体につきVero 細胞 で分離を試みたところ，この細胞で EV-71が分離され た.すでにほかの細胞で分離されたウイルスに対しては, 分離ウイルス型と同じ抗血清を加え再分離を試みた。 そ の結果, 表 3 に示されるように咽頭ぬぐい液から EV-71 を 4 株，ふ九便から EV-71を14株，Cox. B-5 1 株, 
表 4 Crossneutralization of viruses relating to HFMD

\begin{tabular}{lcccc}
\hline \multirow{2}{*}{ Virus } & \multicolumn{3}{c}{ Rabbit immune sera } \\
\cline { 2 - 5 } & Cox. A 16(G-10) & T-73-23-Th & Ty-22-F & Enterovirus 71(BrCpr) \\
\hline Coxsackievirus A 16 (G-10) & $101^{* *}$ & $<4$ & $<4$ & $<4$ \\
T-73-23-Th* & $<4$ & 4096 & 4096 & 128 \\
Ty-22-F* & $<4$ & 2048 & 2048 & 101 \\
Enterovirus 71 (BrCr) & $<4$ & 1618 & 1618 & 1024 \\
\hline
\end{tabular}

* Isolated strain from patient with HFMD in Gifu in 1973. ** Reciprocal of serum dilution

Cox. A-9 1 株分離された.

乳のみマウスでの分離： 26 検体につき皮下に0.03 $\mathrm{ml}$ ずつ接種し，接種後 2 週間観察したが，定型的な四 肢の弛緩性まひを示したすのは認められなかった，1検 体が 4 日め軽度の号緩性まひを示したが，5 日めには その程度は軽減し，8日めまで進行を示さなかった，そ のマウスをと殺し, 胴体部乳剤の遠心上清をVero 細胞 に接種し 2 代継代後, 同定した結果 EV-71であった. な扝，Vero 細胞を 3 代継代した分離株（13株）を乳の みマウスの皮下に $0.03 \mathrm{ml}$ 接種した結果, $4 \sim 5$ 日にす べての株がマウスの四肢に弛緩性まひをおこした。

3. 分離ウイルスの同定： MK 細胞で分離された 6 株中 5 株は, 20単位の Schmidt pool 血清で容易に同定 され，1株が Cox. B-5， 4 株が Cox. A-9 であった. しかし, 残り 1 株は, Schmidt pool 血清, Cox. A-16 抗血清, EV-71抗血清でも中和されなかった.

HeLa 細胞で分離された 9 株は Schmidt pool 血清 で, すべて Cox. B-5 と同定された.

Vero 細胞および乳のみマウスで 分離された 19 株は 20 単位の Schmidt pool 血清, Cox. A-16標準株抗血清で まったく中和同定されなかった。 しかし，73年代表分離 株（T-73-23-Th）に対する抗血清ではすべての株が容易 に中和さ礼た．EV-71 ( $\mathrm{BrCr})$ 抗血清でもすべての株が 中和された，その結果，これら19株のウイルスは，す心゙ て EV-71であると同定された。

4. EV-71分離株の抗原分析：Cox. A-16標準株 (G10) と流行代表株（T-73-23-Th, Ty-22-F）および EV-71 (BrCr) の交差中和試験の結果は表 4 亿示されるようで あった. 73年分離株は Cox. A-16標準株に対する抗血 清に対して,中和抗体価は 4 倍以下であり, EV-71( $\mathrm{BrCr}$ ) も同じ成績であった. 分離株 2 株に対する抗血清は Cox. A-16 (G-10) を全然中和しなかった. $\mathrm{BrCr}$ 株はこの血 清で分離株と同程度に中和された. EV-71 ( $\mathrm{BrCr}$ ) 抗血 清は Homoの $\mathrm{BrCr}$ 株には中和抗体価は1,024倍であ ったが, 73 年分離株に対しては約 $1 / 10$ の抗体価であった. Cox. A-16はこの血清で 4 倍以下の中和抗体価であっ
た. 73年分離株は血清学的に Cox. A-16ではなく, EV71 であることが確認された。

5. 患者血清の中和抗体価：24人の患者ペア血清に つき，表 1 に示した 4 種のウイルス型に対して中和抗体 価を測定した結果は，図3に示すＥV-71に対し有意上 昇したものは 6/24 (25\%)であり, Cox. A-16亿対して有 意上昇したものは $1 / 24$ (4\%)であり,Cox. B-5 亿対して 有意上昇をしたものは $3 / 23$ (13\%)であり, Cox. A-9 に対 して有意上昇したものは $1 / 6$ （17\%）であった。分離材 料からは EV-71, Cox. A-9, Cox. B-5 が分離された が，被検血清はこれらいずれのウイルス型に対しても有 意上昇が認められたが，EV-71に対し高頻度で中和抗体 価の有意上昇が認められた。

中枢神経症状を合併した患者血清の中和抗体価の変 動：表 2 に示すように, 中枢神経症状の合併した患者 からは EV-71と Cox. B-5 と同定不能ウイルスが分離さ れた。 これら患者でペア血清の採取できた患者は10名で あった。表 5 は Cox. A-16, EV-71, Cox. B-5, Cox. A-9 亿対する中和抗体価を測定した結果である.ペア血 清では Cox. A-16と Cox. B-5 に対して有意上昇を示 したものは認められなかった. しかし，Cox. A-16に対 する抗体を保有するもの 3 名，Cox. B-5 亿対する抗体 を保有するもの 2 名認められた。 いっぽう，EV-71に対 して有意上昇を示したものは 3 名であったが，10名とも 抗体を保有していた，症例 2 と症例12は脳炎を合併した 症例であるが，症例 2 では EV-71と Cox. B-5 に対して 抗体を保有していたが有意上昇は認められなかった，症 例12は死亡例のため回復期血清が得られなかったが，急 性期血清では EV-71に対して抗体を保有しなかったが, Cox. B-5 に対しては高い抗体価を保有していた.

\section{考察}

HFMD の病原ウイルスは, Cox. A-16であると成書 には書かれているが，そのほかに Cox. A-群の 4，5， $6,8,9,10$ 型3,5,7,8,11,14,16,19,22,24,25,26,32), Cox. B群の $1 ， 3 ， 4 ， 5$ 型4,15,19,85,38)，ECHO ウイルスの 

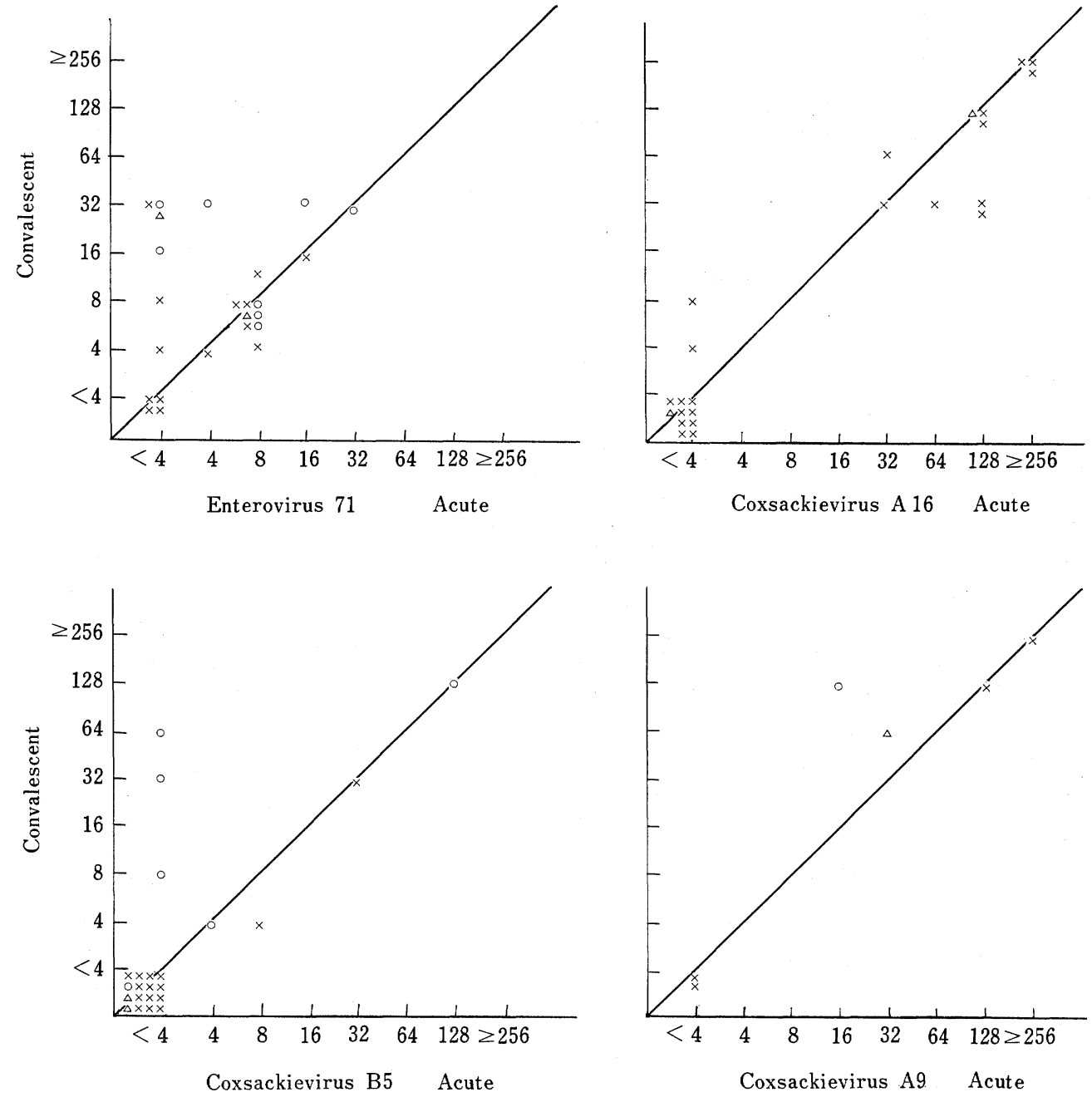

- Virus isolation positive

$\times$ Virus isolation negative

$\Delta$ Virus isolation not done

図 3 Neutralization antibodies against enteroviruses in paired sera

6, 9 型19,26,32)などが HFMD 患者から分離されている.

Cox. A-6，8型を除いてこれらウイルスはいずれも発 疹性ウイルスである。

1970年日本での HFMD の大流行の病原ウイルスは Cox. A-16である33) と報告されているが，そのほかに Cox. A-群の 2， 4， 5，6，8，10型14,17,25,26,29), Cox. B-群の $3 ， 4$ 型15,35,88)を分離している. HFMD の流行期がほかの Enterovirus の流行期と同時期であ るので，これら Enterovirus が分離されるのは不思議 ではない，しかし，これら分離ウイルスと HFMD の病
因的関係を十分に検討している報告は少ない，奥原ら 25) は，血清学的に検討した結果，Cox. A-5，6，10型は Cox. A-16にほぼ近い病因的意義を有すると推定してい る.

著者らは1973年の HFMD 患者から分離したウイルス を同定した結果を表 2 , 表 3 に示した. EV-71分離患者 は $16 / 38$ (42.1\%), Cox. B-5 分離患者は $8 / 88$ (21.1\%)， Cox. A-9 分離患者は $2 / 38$ (5.3\%) であった. HFMD 患者の水疮内容液よりウイルスが分離されれば，そのウ イルスが HFMD の病原ウイルスであると決定すること 
表 5-a. Neutralization antibody titers of HFMD patients with symptom of the central nervous system.

\begin{tabular}{|c|c|c|c|c|c|c|c|c|c|}
\hline $\begin{array}{l}\text { Case } \\
\text { No. }\end{array}$ & Age & Sex & $\begin{array}{l}\text { Onset of } \\
\text { illness }\end{array}$ & $\begin{array}{l}\text { Virus } \\
\text { isolation }\end{array}$ & $\begin{array}{l}\text { Day after } \\
\text { onset }\end{array}$ & EV-71 & $\begin{array}{r}\text { N. } \\
\text { Cox.B-5 }\end{array}$ & $\begin{array}{l}\text { T. titer } \\
\text { Cox.A-16 }\end{array}$ & Cox.A-9 \\
\hline 1 & $1 y$ & $\mathrm{~F}$ & $8 / 21 / 73$ & $\begin{array}{l}\mathrm{EV}-71 \\
\quad+\text { Cox. B-5 }\end{array}$ & $\begin{array}{r}3 \\
15\end{array}$ & $\begin{array}{r}<4^{*} \\
16\end{array}$ & $\begin{array}{l}4 \\
4\end{array}$ & $\begin{array}{l}<4 \\
<4\end{array}$ & \\
\hline 2 & $1 y$ & $\mathrm{M}$ & $8 / 25 / 73$ & $\begin{array}{l}\mathrm{EV}-71 \\
\quad+\text { Cox. B-5 }\end{array}$ & $\begin{array}{r}3 \\
27\end{array}$ & $\begin{array}{l}32 \\
16\end{array}$ & $\begin{array}{l}128 \\
128\end{array}$ & $\begin{array}{l}<4 \\
<4\end{array}$ & \\
\hline 3 & $1 y$ & $\mathrm{~F}$ & $8 / 26 / 73$ & - & $\begin{array}{r}4 \\
18\end{array}$ & $\begin{array}{l}8 \\
8\end{array}$ & $\begin{array}{l}<4 \\
<4\end{array}$ & $\begin{array}{r}8 \\
<4\end{array}$ & \\
\hline 4 & $4 y$ & $\mathrm{M}$ & $9 / 1 / 73$ & $\mathrm{EV}-71$ & $\begin{array}{r}4 \\
18\end{array}$ & $\begin{array}{l}32 \\
32\end{array}$ & $\begin{array}{l}<4 \\
<4\end{array}$ & $\begin{array}{l}<4 \\
<4\end{array}$ & \\
\hline 5 & $1 y$ & $\mathrm{M}$ & $9 / 22 / 73$ & $\mathrm{EV}-71$ & $\begin{array}{r}4 \\
17\end{array}$ & $\begin{array}{l}8 \\
8\end{array}$ & $\begin{array}{l}<4 \\
<4\end{array}$ & $\begin{array}{l}<4 \\
<4\end{array}$ & \\
\hline 6 & $1 y$ & $\mathrm{M}$ & $10 / 2 / 73$ & EV-71 & $\begin{array}{r}4 \\
18\end{array}$ & $\begin{array}{r}4 \\
32\end{array}$ & $\begin{array}{l}<4 \\
<4\end{array}$ & $\begin{array}{r}<4 \\
4\end{array}$ & \\
\hline 7 & $1 y$ & $\mathrm{M}$ & $9 / 29 / 73$ & $\begin{array}{l}\mathrm{EV}-71 \\
\quad+\text { Cox. B-5 }\end{array}$ & $\begin{array}{r}4 \\
18\end{array}$ & $\begin{array}{l}8 \\
8\end{array}$ & $\begin{array}{l}<4 \\
<4\end{array}$ & $\begin{array}{l}<4 \\
<4\end{array}$ & \\
\hline 8 & $3 y$ & $\mathrm{~F}$ & $7 / 5 / 73$ & EV-71 & $\begin{array}{r}5 \\
20\end{array}$ & $\begin{array}{l}8 \\
8\end{array}$ & $\begin{array}{l}<4 \\
<4\end{array}$ & $\begin{array}{l}512 \\
512\end{array}$ & $\begin{array}{l}128 \\
128\end{array}$ \\
\hline 9 & $9 \mathrm{~m}$ & $\mathrm{M}$ & $7 / 16 / 73$ & - & $\begin{array}{r}4 \\
67\end{array}$ & $\begin{array}{r}<4 \\
8\end{array}$ & $\begin{array}{l}<4 \\
<4\end{array}$ & $\begin{array}{l}<4 \\
<4\end{array}$ & $\begin{array}{l}256 \\
256\end{array}$ \\
\hline 10 & $1 y$ & $\mathrm{~F}$ & $8 / 21 / 73$ & - & $\begin{array}{r}4 \\
21\end{array}$ & $\begin{array}{r}8 \\
<16\end{array}$ & $\begin{array}{l}<4 \\
<16\end{array}$ & $\begin{array}{l}<4 \\
<4\end{array}$ & $\begin{array}{l}<4 \\
<4\end{array}$ \\
\hline
\end{tabular}

* Reciprocal of serum dilution

表 5-b. Neutralization antibody titers of HFMD patients with symptom of the central nervous system.

\begin{tabular}{|c|c|c|c|c|c|c|c|c|c|}
\hline \multirow{2}{*}{$\begin{array}{l}\text { Case } \\
\text { No. }\end{array}$} & \multirow{2}{*}{ Age } & \multirow{2}{*}{ Sex } & \multirow{2}{*}{$\begin{array}{c}\text { Onset of } \\
\text { illness }\end{array}$} & \multirow{2}{*}{$\begin{array}{l}\text { Virus } \\
\text { isolation }\end{array}$} & \multirow{2}{*}{$\begin{array}{c}\text { Day after } \\
\text { onset }\end{array}$} & \multicolumn{4}{|c|}{ N. T. titer } \\
\hline & & & & & & $\mathrm{EV}-71$ & Cox.B-5 & Cox.A-16 & Cox.A-9 \\
\hline 11 & $9 y$ & $\mathrm{~F}$ & $8 / 24 / 73$ & - & 7 & $32 *$ & 128 & 64 & \\
\hline 12 & $9 \mathrm{~m}$ & $\mathrm{M}$ & $9 / 3 / 73$ & - & 5 & $<4$ & $>512$ & $<4$ & \\
\hline 13 & $3 y$ & $\mathrm{~F}$ & $9 / 8 / 73$ & - & 3 & 16 & $<4$ & 512 & \\
\hline 14 & $3 y$ & $\mathrm{M}$ & $9 / 21 / 73$ & E V-71 & 18 & 8 & $<4$ & 8 & \\
\hline 15 & $3 y$ & $\mathrm{~F}$ & $9 / 27 / 73$ & E V -71 & 2 & $<4$ & $<4$ & 256 & \\
\hline 16 & $1 y$ & $\mathrm{M}$ & $10 / 1 / 73$ & E V-71 & 4 & & $<4$ & $<4$ & \\
\hline 17 & $1 y$ & $\mathrm{M}$ & $7 / 18 / 73$ & $\begin{array}{l}\text { F V-71 } \\
\quad+\text { Cox. B-5 }\end{array}$ & 22 & 8 & $<4$ & $<4$ & \\
\hline 18 & $3 y$ & $\mathrm{M}$ & $8 / 5 / 73$ & - & 5 & 8 & $<4$ & $<4$ & $<4$ \\
\hline
\end{tabular}

ができるが，著者らの検査材料には水炮内容液を得るこ とができなかった。 それ肪え，、ちばん多く分離された ウイルスが EV-71であったので，1973年の HFMD の 主病原ウイルスは EV-71であると推定される. Cox. B5 拈よび Cox. A-9 は, HFMD 以外の患者加らも分離 されているので，同時期に流行したウイルスと考えられ る.しかし，HFMD 患者で Cox. B-5 の分離例では，

Cox. B-5 に対して中和抗体価の 有意上昇が 3 名あった ことと，EV-71が重複分離された症例が 4 名認められた ことより，Cox. B-5 \& HFMD の発症になんらかの役
割を果たしているかもしれない

1973年流行した HFMD のうち, 著者らの検査対象が 中枢神経合併の認められるようになってから以後であっ たためか, 皮膚粘膜症状のほかに中枢神経症状を合併し た症例が多かった. 1973年の HFMD の流行の主病原ウ イルスが EV-71であることが明らかとなった現在で は10)，中枢神経症状を合併したことは不思議なことでは ない.むしろ, Schmidt ら ${ }^{31)}$, Deibel ら ${ }^{6)}$, Blomberg ら2の EV-71の症例は, 中枢神経症状が主であり,HFMD の症例は少数例に過ぎない. 著者らが検査した中枢神経 
合併症の HFMD の症例は表 5 に示したように, 7/20 (35 \%) より EV-71が単独分離され，4/20 (20\%) は EV-71 と Cox. B-5 が重複分離され，1/20 (5\%) は同定不能ウ イルスが分離された. Cox. B-5のみ単独分離されたも のはなく, Cox. B-5 に対して中和抗体の有意上昇を示 したものもなかった. また，無菌性髄膜炎の症例より EV-71が分離されていることより，HFMD に続発した 無菌性髄膜炎は EV-71によるものと推定される. しか し，HFMD と脳炎を合併した症例は，症例 2 では髄液 より Cox. B-5 が分離されたことと，症例12（死亡例） は剖検材料および咽頭ぬぐい液, ふん便などからウイル スが分離されず，急性期血清で Cox. B-5 に対して高い 抗体価を示したにもかかわらず，EV-71に対する抗体価 は4 倍以下であったので, Cox. B-5 がこれら脳炎の主 病原ウイルスと推定される.

ウイルス分離をおこなった 38 症例中 22 症例 (57.9\%) よりウイルスが分離された，そのらち，EV-71の分離症 例は 16 例 (42.1\%), EV-71以外のウイルス分離症例は 6 例 $(15.8 \%), 16$ 症例はウイルスが分離できなかった. 1973年流行した EV-71は，表 3 から明らかなように， MK や S.M. での分離率よりもVero 細胞での分離率 が高かった. 山周ら ${ }^{37}$ ，中村ら 233 離しているが，著者らはまったく分離できなかった。 そ の理由は明らかではない，中村ら ${ }^{23}$ は患者ふん便材料を マウスに接種して Cox. A 群の定型的四肢まひを接種 マウスの全例に認めているが，著者らは $1 / 21(4.8 \%)$ に 非定型的まひを認めたに過ぎなかった. Schmidt ら ${ }^{31)}$, Deibel 56)も EV-71のマウスでの病原性を認めていな W.

患者血清の EV-71に対する有意上昇は $25 \%$ と比較的 低かったが，山岡ら37) HFMD+CND 患者ペア血清 の抗体を調べて有意上昇が $12 / 50(24 \%)$ といら結果を報告 している. いっぽう鈴木ら40)は，EV-71 分離株 73.3752 $\mathrm{m}$ 株に対する中和抗体の有意上昇は63例中37例 (59\%) と報告している．著者らの場合，同時期にほかのエンテ ロウイルスの流行があったためか, 血清の採血時期の不 適によるのか明らかではない，奥原ら25)は，1970年の HFMD の流行において Cox. A-16以外に種々のウイル スを分離し, 血清学的調査もしているが, Cox. A-16が分 離されているにもかかわらず，中和抗体価の有意上昇を 認めなかった例をいくつか示している.このことは,一地 域に同時流行した場合にはウイルス間の干渉により抗体 の上がりにくいことがありらることを示している.いっ ぽう, 山岡ら ${ }^{37}$ は, 採血間隔が 1 か月前後ある患者は抗体 の有意上昇が 8 名中 7 名あったことを報告している. 山 岡 ${ }^{37)}$, 河原 ${ }^{93}$, Schmidt $ら^{31}$, Deibel ら6)
いるように，急性期血清で EV-71に対して比較的高い 抗体価を示した症例が認められるが，著者らも同じよう な傾向を認めた.

\section{謝辞}

ご校閲いただきました岐皁大学医学部鈴木祥一郎教授 に深甚の謝意を表します。

\section{文献}

1) Alsop, J., Flewett, T. and Foster, J. R. (1960): "Hand foot and mouth disease" in Birmingham in 1959. Brit. Med. J., 2, 17081711.

2) Blomberg, J., Lycke, E., Ahlfors, K., Johnsson, T., Wolontis, S. and Zeipel, G. V. (1974) : New enterovirus type associated with epidemic of aseptic meningitis and/or hand, foot, and mouth disease. Lancet, July 13, 112.

3) Burry, J. N., Moore, B. and Mattner, C. (1968) : Hand, Foot and Mouth Disease in South Australia. Med. J. Australia, 2, 587589.

4) Cherry, J. D. and Jahn, C. L. (1966) : Virologic studies of exanthems. J. Pediat., 68, 204-214.

5) Clarke, S. K. R., Morley, T. and Warin, R. P. (1964) : Hand, Foot and Mouth Disease. Brit. Med. J., 1, 58.

6) Deibel, R., Gross, L. L. and Collins, D. N. (1975) : Isolation of a New Enterovirus. Proc. Soc. Exp. Biol. Med., 148, 203-207.

7) Duff, M. F. (1968) : Hand-foot-and-mouth Syndrome in Humans; Coxsackie A 10 Infections in New Zealand. Brit. Med. J., 2, 661-664.

8) Flewett, T. H., Warin, R. P. and Clarke, S. K. R. (1963) : 'Hand, foot and mouth disease' associated with Coxsackie A 5 virus. J. Clin. Path., 16, 53-55.

9）河原富美子, 板垣朝夫, 伊藤義広, 斉藤孝一, 西 野泰生 (1975)：松江市に抢けるエンテロウイル ス感染症の検索成績について (1973.4 1973.10) -HFMD 及び無菌性髄膜炎の流行状況— 感染症学雑誌, 49, 282-287.

10) Hagiwara, A., Tagaya, I. and Yoneyama, T. (1978) : Epidemic of Hand, Foot and Mouth Disease Associated with Enterovirus 71 Infection. Intervirology, 9, 60-63.

11) Hughes, R. O. and Roberts, C. (1972): Hand, Foot and Mouth Disease Associated with Coxsackie A 9 Virus. Lancet, Oct. 7, 751-752.

12）市川哲郎 (1969) : Hand, Foot and Mouth Disease 及びその近縁疾患について，小児科診療， 
32, 161-166.

13）石丸啓郎, 一色正義, 山岡邦夫 (1974) : HandFoot-Mouth Disease によるAtaxia を伴った 無菌性髄膜炎について。医学のあゆみ，89, 108-109.

14）伊藤昭吾, 芦田博之, 岡田正次郎, 甲野正己, 小島竜男, 内山泰宏, 竹越亮一, 浅子実(1970)： 埼玉県に扮ける Hand, Foot and Mouth Disease (HFMD) の流行. 感染症学雑誌, 44 , 508-509.

15）岩崎謙二, 山田澄夫, 佐々木憲子, 柳沢靖子 (1971)：1970年東京都内の Hand, Foot and Mouth Disease の流行時に行ったウイルス検索 成績. 東京都立衛生研究所年報, 22, 41-45.

16) Magoffin, R. L., Jackson, E, W. and Lennette, E. H. (1961) : Vesicular stomatitis and exanthem. A syndrome associated with Coxsackie virus type A 16. J.A.M.A., 175, 441-445.

17）松尾幸子，林薰，里見正義(1971)：1970年, 長崎市および近郷に流行した手足口病 (Hand, Foot and Mouth Disease) の病原ウイルスの 検索. 熱帯医学, 13, 180-184.

18) Melnick, J. L., Tagaya, I. and Magnus, H. V. (1974) : Enterovirus 69, 70 and 71. Intervirology, 4, 369-370.

19) Miller, G. D. and Tindall, J. P. (1968): Hand-Foot-and Mouth Disease. J.A.M.A., 203, 827-830.

20）三輪智恵子, 川本尋義, 吉沢邦重, 松浦章雄 (1974)：昭和48年岐皋県（2地区）の小児科患 者からのエンテロウイルス分離成績. 岐阜県衛 生研究所報, 19, 1-6.

21）三輪智恵子, 野田伸司, 松浦章雄, 吉沢邦重 (1976)：昭和50年岐卓県（2地区）の小児患者 からのエンテロウイルス分離成績. 岐阜県衛生 研究所報, 21, 1-5.

22) 中村兼次, 渡辺悌吉, 北山徹, 浦野純子, 福 見秀雄, 西川文雄 (1965): Coxsackie A 群ウイ ルスによるロ腔粘膜疹を伴う熱性疾患. 小児科 診療, 28, 1004-1012.

23) 中村良子, 後藤則子, 川原 真, 野村 宽, 中 村国衛(1973)：コクサッキーA群16型ウイルス 変異株による感染症について. 名古屋市衛生研 究所報, 20, 30-33.

24）布上 哇, 高林一明, 植田浩司, 永山德郎, 松 本寿通 (1969)：Hand, Foot and Mouth Disease の流行. 日本伝染病学雑誌, 42, 354-355.

25）奥原広治, 估藤七七朗, 桜田教夫, 飯田広夫 (1975)：1970年夏，北海道に流行した Hand, Foot and Mouth Disease 患者から検出された Coxsackie A 群16型とそれ以外の Coxsackie A 群ウイルスについて．ウイルス，25，42-52。

26) 大石 功, 大村 卓, 山田彪史, 光田文吉, 木 本達雄, 川井 昭 (1968) : Hand, Foot and Mouth Disease の患者加の Coxsackie A 4 およびA16の分離について. 大阪府立公衆衛生 研究所研究報告 公衆衛生編, 6, 45-47.
27）大津啓二, 井上博雄 (1975)：Hand, Foot and Mouth Disease に関する研究(第 7 報)—-1973 年, 大阪府全域に流行した HFMD について. 大阪府立公衆衛生研究所研究報告 公衆衛生編, 13, 47-48.

28) Robinson, C. R., Doane, E. W. and Rhodes, A. J. (1958) : Report of an outbreak of febrile illness with pharyngeal lesions and exanthem. Tront, summer 1957 isolatson of group A Coxsackie virus. Canad. Med. Assoc. J., 79, 615-621.

29）斉藤直喜, 小川幹雄, 高宮 篤, 梶岡実雄 (1972)： 1969 1970年, 神奈川県に流行した Hand, Foot and Mouth Disease のウイルス学的調查. 神 奈川県衛生研究所研究報告, 2, 19-24.

30）沢田啓司，中村 豊，伊藤昭吾 (1968)：昭和 42 年夏, 大宮市に流行した Hand, Foot and Mouth Disease について. 日本小児科学会雑誌，72, 1596.

31) Schmidt, N. J., Lennett, E. H. and Ho. H. H. (1974) : An Apparently New Enterovirus Isolated from Patients with Disease of the Central Nervous System. J. Infect. Dis., 129, 304-309.

32) 新海 浤, 前田一郎, 佐野栄春 (1968) : HandFoot-Mouth disease. 皮膚科の臨床，10，363373 .

33) Tagaya, I. and Moritsugu, Y. (1973) : Epidemic of hand, foot and mouth disease in Japan. Japan. J. Med. Sci. Biol., 26, 143-147.

34) 高安 進, 川津友子 (1969)：豊中市に発生した Hand, Foot and Mouth Disease の症例. 臨床 皮膚科, 23, 43-49.

35) 武原雄平, 大塚 悟, 有吉陽一(1971)：福网県 田川市において発生した Coxsackie B による 無菌性髄膜炎と“Hand, Foot and Mouth Disease" の同時流行について. 日本細菌学雑誌, 26, 418-419.

36）渡辺悌吉，浦野純子，河野弘子，石原 裕，藤 原建樹 (1973)：手足口病並びにコクサッキーウ イルスA16感染—之の現状と問題点——. 小 児科診療，36，1427-1442.

37）山岡邦夫，大瀬戸光明，士居陽子，矢野朱， 森 正俊, 曾田研二, 石丸啓郎, 一色正義 (1973) : 1973年愛媛県に流行した手足口病のウイルス学 的検討. 48年度愛媛県衛生研究所年報, 35, 1116.

38）安川史郎，野々村幸雄，石原佑二、，西尾治 (1972) : 昭和45年夏愛知県下の Hand Foot and Mouth 病の発生の概要とウイルス学的検査成 績. 愛知県衛生研究所報, 22, 13-18.

39）吉田英一, 窪田 勉, 野口政輝 (1970)：Handfoot and mouth disease 様患者からのコクサ ッキーA-16型ウイルスの分離. 日本公乑衛生誌, 17, 39-41.

40）鈴木利寿, 餅田照代, 斉藤直喜, 小林一郎, 高宮 篤，金山富美枝 (1977)：神奈川県に流行した手 


\title{
EPIDEMIC OF HAND, FOOT AND MOUTH DISEASE IN GIFU PREFECTURE IN 1973
}

\author{
Chieko MIWA, Fujizo YAMADA, Akio MATSUURA \\ and Kunishige YOSHIZAWA \\ Gifu Prefectural Institute of Public Health \\ Takayama Red Cross Hospital Clinic of Pediatrics \\ Tajimi Hospital Clinic of Pediatrics
}

An epidemic of hand, foot and mouth disease (HFMD) occurred in Gifu Prefecture in 1973. Virological and serological investigation were performed.

Those involved ranged from 0 to 23 years of age, and $71.4 \%$ of them were under 4 years. Symptoms of the central nervous system (CNS) were observed concomitantly in 20 of 42 cases.

Viruses were isolated from 22 of 38 cases $(57.9 \%)$. The types of isolated viruses with the number of cases of isolation are as follows: enterovirus 71(16 cases; 42.1\%), Coxsackievirus (Cox.) B 5 (8 cases; 21.1\%), Cox. A 9 (2 cases; $5.2 \%$ ), and unidentified virus (one case ; $2.6 \%$ ). Cox. A 16 was not isolated at all. Eighteen strains of enterovirus 71 were isolated in Vero cells. One strain was isolated in suckling mice. The viruses isolated from cases of HFMD with CNS symptoms were identified as enterovirus 71 and Cox. B 5 .

In the cross-neutralization test, the isolated strains of enterovirus 71 showed a cross reaction to the prototype strain of enterovirus 71 , but were antigenically broader than this strain. They showed no cross reaction to the prototype strain of Cox. A 16 .

A significant rise of neutralization antibody titer was found in $25 \%$ of 24 cases against enterovirus $71,13 \%$ of 23 cases against Cox. B 5, $4 \%$ of 24 cases against Cox. A 16, and $17 \%$ of 6 cases against Cox. A 9.

It was supposed that the main causative agent of HFMD epidemic in Gifu Prefecture in 1973 might be enterovirus 71 . The roles of the other viruses isolated, however, can not be neglected in the etiology of HFMD. 